\title{
Apa determinan tingkat pengungkapan Islamic Social Reporting bank umum syariah Indonesia?
}

\author{
Ruri Deviani, Hadri Kusuma* \\ Fakulas Ekonomi Universitas Islam Indonesia, Yogyakarta, Indonesia \\ *Coresponding author e-mail: hkusuma@uii.ac.id
}

\section{Keywords:}

Social Reporting, Islamic Governance, Profitability, Liquidity, Age.

DOI:

10.20885/JEKI.vol5.iss1.art5

\begin{abstract}
The inconsistent result of previous studies on the effect of Islamic corporate governance, good corporate governance, profitability, liquidity, and the age of the company may be due to the use of different indicators. This study aims to analyze factors influencing the disclosure index of Islamic Social Reporting (ISR) general Islamic banks for the period of 2014-2017. The research sample was 48 firm-year observations from 12 banks. The statistical tool used to test the hypothesis is using Autoregressive Conditional Heteroskedasticity (ARCH) with the help of Eviews software version 9. The results of this study indicated that the Islamic Corporate Governance and age of the banks are the determinants of the ISR while Good Corporate Governance, Liquidity and profitability variables have no effect on the ISR disclosure.
\end{abstract}

\begin{abstract}
Abstrak
Ketidakkonsitenan hasil pada penelitian-penelitian terdahulu mengenai Islamic corporate governance, good corporate governance, profitabilitas, likuiditas, dan umur perusahaan disebabkan karena menggunakan indikator yang berbeda. Penelitian ini bertujuan untuk menganalisis determinan yang berpengaruh terhadap pengungkapan Islamic Social Reporting (ISR) perbankan syariah di Indonesia. Sampel penelitian ini sebanyak 48 laporan tahunan dari 12 bank umum syariah. Alat statistik yang digunakan dalam penelitian adalah Autoregresive Conditional Heteroskedasticity (ARCH) dengan bantuan software Eviews. Hasil dari penelitian ini menunjukkan bahwa variabel Islamic Corporate Governance dan umur perusahaan berpengaruh signifikan terhadap tingkat pengungkapan ISR. Good Corporate Governance, likuiditas dan profitabilitas tidak berpengaruh terhadap tingkat pengungkapan ISR.
\end{abstract}

\section{Pendahuluan}

Sektor keuangan syariah yang berkembang cukup pesat tidak lepas dari peran lembaga keuangan syariah yakni perbankan syariah. Di Indonesia, bank syariah mulai dikenal pada tahun 1991 dengan berdirinya Bank Muamalat Indonesia dan resmi beroperasi pada Mei 1992. Bank syariah adalah Bank yang menjalankan kegiatan usahanya berdasarkan Prinsip Syariah. Menurut data statistik perbankan syariah yang dikeluarkan oleh Otoritas Jasa Keuangan (OJK), pada tahun 2018 tercatat Indonesia telah memiliki 14 perbankan syariah (Otoritas Jasa Keuangan 2018). Undang-undang No. 21 Tahun 2008 tentang perbankan syariah menyebutkan bahwa perbankan syariah bertujuan menunjang pelaksanaan pembangunan nasional dalam rangka meningkatkan keadilan, kebersamaan, dan pemerataan kesejahteraan rakyat. (Undang-undang No. 21 Tahun 2008, p.7)

Perbankan syariah menjalankan fungsi ekonomi sebagai penghimpun dana dan menyalurkan dana masyarakat, selain itu bank syariah juga wajib menjalankan fungsi sosial dalam bentuk Baitul Mal yang disebutkan juga dalam Peraturan Perundang-undangan No. 21 Tahun 2008, yaitu menerima dana yang berasal dari zakat, infak, sedekah, hibah, atau dana sosial lainnya dan menyalurkannya kepada organisasi pengelola zakat (Lestari 2016). Dengan begitu perbankan syariah wajib untuk menginformasikan pertanggungjawaban sosial yang sudah dilaksanakan.

Konsep Corporate Social Responsibility (CSR) kini tidak hanya berkembang di ekonomi konvensional, tetapi juga berkembang dalam ekonomi Islam. Konsep CSR dalam Islam erat kaitannya dengan perusahaanperusahaan yang menjalankan kegiatan bisnis sesuai dengan konsep syariah. Perusahaan-perusahaan diharapkan dapat melaksanakan tanggung jawab sosial perusahaannya secara baik dan konsisten terhadap nilai-nilai Islam 
(Astuti, 2013). Di samping itu, konsep pertanggungjawaban sosial mengedepankan prinsip syariah dan mengungkapkan adanya keterbatasan dalam pelaporan sosial konvensional. Hal ini mendorong adanya kerangka konseptual Islamic Social Reporting yang berdasarkan ketentuan syariah yang tidak hanya membantu pengambilan keputusan bagi pihak muslim melainkan juga untuk membantu perusahaan dalam melakukan pemenuhan kewajibannya terhadap Allah SWT dan masyarakat sekitar (Othman et al. 2009). Selanjutnya, menurut Anggraini dan Wulan (2017) Islamic Social Reporting (ISR) merupakan perluasan dari pelaporan sosial yang tidak hanya berupa keinginan besar dari seluruh masyarakat terhadap peranan perusahaan dalam kegiatan ekonominya saja melainkan juga berkaitan dengan perspektif spiritual yang berlandaskan prinsip syariah.

Beberapa penelitian telah membahas topik pengungkapan Islamic social reporting, seperti Othman, Thani dan Ghani (2009); Firdaus (2017); Anggraini dan Wulan (2017); Hartawati, Sulindawati, dan Kurniawan (2017). Akan tetapi secara umum penelitian-penelitian tersebut menunjukan hasil yang belum konsisten dan dengan determinan yang berbeda. Kemungkinan besar penyebab perbedaan hasil tersebut adalah karena perbedaan proksi yang digunakan untuk setiap determinan. Misal, penelitian Dewi dan Priyadi (2013), dan Masyitah (2016) menggunakan kepemilikan manajerial sebagai indikator Good Corporate Governance (GCG) sementara Firdaus (2017); dan Ningrum, Fachrurrozie dan Jayanto (2013) menggunakan kepemilikan institusi. Selanjutnya, indikator proporsi dewan komisaris independen digunakan oleh Charles dan Chariri (2012); Ramdhaningsih dan Utama (2013), dan komite audit diteliti oleh Hartawati, Sulindawati, dan Kurniawan (2017) sebagai proksi GCG.

Untuk variabel profitabilitas, Harahap et al. (2017), Rosiana, et al (2015) menggunkan proksi return on asset, penelitian yang dilakukan Astuti (2013) menggunakan indikator return on equity, dan Masyitah (2016) menggunakan net profit margin. Untuk variabel likuiditas, Masyitah (2016) dan Astuti (2013) menggunakan current ratio sebagai indikatornya sementara Nadlifiyah dan Laila (2016) menggunakan indikator loan to deposito ratio atau financing to deposit ratio. Terakhir, Nasir, et al (2013) menggunakan indikator umur perusahaan yang dihitung sejak tahun berdirinya perusahaan sampai dengan tanggal laporan keuangan, sedangkan Sunaryo dan Mahfud (2016) dan Widiyanti dan Hasanah (2015) menghitung semenjak pertama kali listing.

Penelitian ini bertujuan untuk menganalisa determinan tingkat pengungkapan Islamic social reporting (ISR) bank umum syariah di Indonesia. Akan tetapi penelitian ini berbeda dengan penelitian-penelitian sebelumnya. Pertama, penelitian ini menggunakan determinan-determinan yang belum menunjukan konsistensi hasil. Kedua, penelitian ini menggunakan proksi tunggal yang berupa efisiensi dari setiap determinan. Input-input setiap variabel dihubungkan dengan output sehingga menghasilkan nilai efisiensi. Penelitian ini menggunakan Data Envelopment Analysis (DEA) sebagai alat bantu. DEA adalah pendekatan pemrograman matematis untuk memberikan nilai efisiensi relatif dari beberapa indikator pada suatu variabel baik sebagai input maupun output. Tingkat efisiensi dari determinan-determinan tersebut kemudian digunakan untuk menjelaskan tingkat pengungkapan Islamic Social Reporting (ISR).

Untuk menjawab tujuan penelitian tersebut, penelitian ini menggunakan tiga teori: teori keagenan, legitimasi dan stakeholder. Konsep teori keagenan (Agency Theory) di dasari pada permasalahan agensi yang muncul ketika pengurusan suatu perusahaan terpisah dari kepemilikannya (Jensen dan Meckling 1976). Perusahaan merupakan mekanisme yang memberikan kesempatan kepada berbagai partisipan untuk berkontribusi dalam bentuk modal, keahlian serta tenaga kerja dalam rangka memaksimumkan keuntungan jangka panjang. Partisipan-partisipan yang berkontribusi pada modal disebut sebagai pemilik. Partisipan-partisipan yang berkontribusi dalam keahlian dan tenaga kerja disebut pengelola perusahaan (agen). Adanya dua partisipan tersebut (principal dan agen) menyebabkan timbulnya permasalahan tentang mekanisme yang harus di bentuk untuk menyelaraskan kepentingan yang berbeda diantara keduannya (Sunaryo \& Mahfud, 2016).

Teori keagenan bertujuan untuk menyelesaikan masalah-masalah yang mungkin terjadi. Masalah yang pertama yakni masalah agensi yang timbul ketika adanya konflik tujuan antara pemilik perusahaan dan manajemen serta kesulitan pemilik perusahaan melakukan verifikasi pekerjaan manajemen. Kedua, masalah pembagian risiko yang muncul ketika pemilik perusahaan dan manajemen memiliki perilaku yang berbeda terhadap muculnya risiko. Masalah ini timbul karena perbedaan tindakan yang disebabkan adanya perbedaan preferensi risiko. Jensen dan Meckling (1976) berpendapat bahwa konflik dalam suatu perusahaan dapat terjadi karena adanya pemisahan antara pemegang saham dengan manajemen (agency problem). Dengan adanya kepemilikan saham oleh pihak manajemen akan memperkecil adanya konflik atau agency problem tersebut. Manajemen atau agen berusaha untuk memaksimalkan kepentingan dirinya dibandingkan kepentingan perusahaan.

Menurut Eksandy dan Hakim (2015) legitimasi merupakan keadaan psikologis keberpihakan orang ataupun kelompok orang yang sangat peka terhadap gejala lingkungan sekitarnya, baik fisik maupun nonfisik. Legitimasi masyarakat merupakan faktor strategis bagi perusahaan dalam rangka mengembangkan perusahaan kedepan. Hal itu dapat dijadikan sebagai sarana untuk membangun strategi perusahaan, terutama terkait dengan upaya memposisikan diri di tengah lingkungan masyarakat yang semakin berkembang dan kompleks. Teori legitimasi juga berhubungan dengan pengungkapan sosial perusahaan. legitimacy theory secara esensial adalah teori yang berorientasi pada sistem, dalam hal ini organisasi atau perusahaan dipandang sebagai salah satu 
komponen dalam lingkungan sosial yang lebih besar. Teori legitimasi menyediakan perspektif yang lebih komprehensif pada pengungkapan sosial. Teori ini secara eksplisit mengakui bahwa bisnis dibatasi oleh kontrak sosial yang menyebutkan bahwa perusahaan sepakat untuk menunjukkan berbagai aktivitas sosial perusahaan agar diterima masyarakat akan tujuan perusahaan yang pada akhirnya akan menjamin kelangsungan hidup perusahaan (Nasir et al, 2013).

Pemangku kepentingan (Stakeholder) adalah orang atau kelompok yang memiliki, atau mengklaim, kepemilikan, hak, atau kepentingan dalam suatu perusahaan dan kegiatannya pada masa lalu, sekarang, atau masa depan. Hak atau kepentingan yang diklaim seperti itu adalah hasil dari transaksi dan/atau tindakan yang diambil oleh korporasi, bersifat legal, secara individu ataupun kolektif. Pemangku kepentingan dengan daya tarik yang sama, klaim, atau hak yang sama dapat diklasifikasikan sebagai milik kelompok yang sama seperti: karyawan, pemegang saham, pelanggan, dan sebagainya (Clarkson 1995). Menurut Lindawati dan Puspita (2015), teori stakeholder merupakan suatu teori yang menyatakan keberlangsungan suatu perusahaan tidak terlepas dari adanya peranan stakeholders, baik dari internal maupun eksternal dengan berbagai latar belakang kepentingan yang berbeda dari setiap stakeholder yang ada. Corporate Social Resposibility (CSR), misalnya, dapat menjadi strategi perusahaan untuk memenuhi kepentingan dari para stakeholder akan informasi non-keuangan perusahaan terkait dampak sosial dan lingkungan yang timbul dari adanya aktivitas perusahaan. Semakin baik pengungkapan CSR oleh perusahaan akan membuat stakeholder memberikan dukungan penuh kepada perusahaan atas segala aktivitasnya yang bertujuan untuk meningkatkan kinerja dan mencapai laba yang diharapkan.

\section{Metode Penelitian}

Populasi yang digunakan dalam penelitian ini adalah seluruh bank umum syariah di Indonesia. Pengambilan sampel dilakukan dengan menggunakan teknik purposive sampling, dengan kriteria terdaftar sebagai bank umum syariah sesuai statistik yang terdaftar di Otoritas Jasa Keuangan (OJK), dan memiliki laporan keuangan periode 2014-2017. Dengan menggunakan kriteria tersebut, penelitian ini menggunakan 12 bank umum syariah dari 14 bank atau 48 data tahunan yang datanya bisa diproses untuk mencapai tujuan penelitian ini.

Jenis data yang digunakan dalam penelitian ini adalah data sekunder dan diperoleh dari website yaitu https://www.ojk.go.id maupun website dari masing-masing bank umum syariah di Indonesia. Metode pengumpulan data yang digunakan adalah metode dokumentasi, yaitu mendokumentasikan semua indikator yang diperlukan untuk memproksikan setiap variabel. Tabel 1 menunjukan proksi masing masing variabel beserta rujukannya.

Tabel 1. Variabel dan Pengukuran

\begin{tabular}{|c|c|c|}
\hline Variabel & Indikator & Referensi \\
\hline Islamic Social Reporting (ISR) & $\begin{array}{l}\text { Disclousure } \\
\text { Level }= \\
\qquad \frac{\text { Jumlah skor yang dipenuhi }}{\text { Jumlah Skor Maksimum }}\end{array}$ & Arifah (2018) \\
\hline Islamic Corporate Governance (ICG) & Jumlah dewan pengawas syariah & $\begin{array}{l}\text { Ningrum, Fachrurrozie, dan Jayanto } \\
\text { (2013); dan Khoirudin (2013) }\end{array}$ \\
\hline Umur perusahaan (AGE) & Lama menjadi bank umum syariah & $\begin{array}{l}\text { Widiyanti dan Hasanah (2015); } \\
\text { Lestari (2016); dan Nadlifiyah dan } \\
\text { Laila (2016). }\end{array}$ \\
\hline Good Corporate Governance (GCG) & Efisiensi GCG & Kusuma dan Ayumardani (2016). \\
\hline Profitabilitas (PROF) & Efisiensi profitabilitas & Kusuma dan Ayumardani (2016). \\
\hline Likuiditas (LIK) & Efisiensi likuiditas & Kusuma dan Ayumardani (2016). \\
\hline
\end{tabular}

Pada penelitian ini menggunakan Data Envelopment Analysis (DEA) untuk mengukur tingkat efisiensi Good Corporate Governance (GCG) setiap tahunnya. Rumus efficiency adalah:

$$
E f f=\frac{\sum_{i}^{m} u y}{\sum_{i}^{m} v x}
$$

Dmana, Eff adalah tingkat efisiensi, $u$ adalah output berupa pendapatan operasional, total aset, total ekuitas, $y$ adalah jumlah dari output, $v$ adalah Input seperti pada Tabel 2, dan $x$ adalah jumlah dari input 
Tabel 2. Input dan Referensi

\begin{tabular}{|c|c|c|}
\hline Variabel & Input & Referensi \\
\hline \multirow[t]{4}{*}{$\begin{array}{l}\text { Good Corporate } \\
\text { Governance }(G C G)\end{array}$} & $\begin{array}{l}\text { Kepemilikan Manajerial = persentase jumlah } \\
\text { lembar saham yang dimiliki oleh pihak } \\
\text { manajemen }\end{array}$ & $\begin{array}{l}\text { Assegaf, Falikhatun dan Wahyuni } \\
\text { (2012); Nasir, Kurnia dan Hakri (2013); } \\
\text { dan Ramdhaningsih dan Utama (2013) }\end{array}$ \\
\hline & $\begin{array}{l}\text { Kepemilikan institusional = presentase jumlah } \\
\text { saham milik institusi }\end{array}$ & Firdaus (2017). \\
\hline & Komite audit $=$ jumlah komite audit & $\begin{array}{l}\text { Hartawati, Sulindawati dan Kurniawan } \\
\text { (2017); dan Haribowo (2015) }\end{array}$ \\
\hline & $\begin{array}{l}\text { Proporsi Dewan komisaris = rasio jumlah } \\
\text { anggota dewan komisaris independen }\end{array}$ & $\begin{array}{l}\text { Santioso dan Chandra (2012); Dewi dan } \\
\text { Priyadi (2013); dan Ramdhaningsih dan } \\
\text { Utama (2013) }\end{array}$ \\
\hline \multirow[t]{4}{*}{ Profitabilitas } & ROA= Laba Sebelum Pajak/Total Aset & $\begin{array}{l}\text { Ramadhani (2014); dan Nadlifiyah dan } \\
\text { Laila (2016) }\end{array}$ \\
\hline & ROE $=$ Laba Setelah Pajak/Total Ekuitas & $\begin{array}{l}\text { Astuti (2013); dan Hartawati, } \\
\text { Sulindawati, dan Kurniawan (2017) }\end{array}$ \\
\hline & $\begin{array}{l}\text { NPM = Laba setelah Pajak/Pendapatan } \\
\text { Operasional }\end{array}$ & Anggraini dan Wulan (2017) \\
\hline & $\begin{array}{l}\text { BOPO=Belanja Operasional/Pendapatan } \\
\text { Operasional }\end{array}$ & Febrianty (2017) \\
\hline \multirow[t]{4}{*}{ Likuiditas } & Current Ratio = Aktiva Lancar/Hutang Lancar & $\begin{array}{l}\text { Widiyanti dan Hasanah (2015); Astuti } \\
\text { (2013); dan Lestari (2016) }\end{array}$ \\
\hline & Quick Ratio = Cash Aset/Total Deposit & Arifin dan Syukri (2006) \\
\hline & Cash Ratio = Kas - Setara Kas/Hutang Lancar & Arifin dan Syukri (2006) \\
\hline & $\begin{array}{l}\text { FDR = Total Pembiayaan/Total Dana Pihak } \\
\text { Ketiga }\end{array}$ & Nadlifiyah dan Laila (2016) \\
\hline
\end{tabular}

Pengujian mengenai pengaruh faktor-faktor yang mempengaruhi tingkat pengungkapan Islamic Social Reporting (ISR) perbankan syariah menggunakan regresi linier berganda. Penelitian ini mengggunakan model Autoregresive Conditional Heteroskedasticity (ARCH) untuk mengukur seberapa besar hubungan variabel independen dan variabel dependen. Persamaan regresi yang digunakan adalah sebagai berikut:

$$
I S R=\alpha+\beta_{1} I C G+\beta_{2} G C G+\beta_{3} P R O F+\beta_{4} L I K+\beta_{5} A G E+e
$$

Dimana, ISR adalah pengungkapan Islamic Social Reporting, $\alpha$ adalah konstanta, ICG adalah Islamic Corporate Governance, GCG adalah Good Corporate Governance, profitablitas adalah kemampulabaan, LIK adalah likuiditas, AGE adalah umur perusahaan, $\beta_{1}-\beta_{5}$ adalah koefisien regresi parsial dan $\varepsilon$ adalah koefisien error

\section{Hasil dan Pembahasan}

Tabel 3 menunjukan deskriptif data setiap variabel. Semua variabel memiliki nilai rata-rata (Mean) diatas nilai standar deviasinya. Hasil ini mengindikasikan determinan tersebut berdistribusi normal.

Tabel 3. Deskripsi Data

\begin{tabular}{lcccrcc}
\hline & ISR & ICG & GCG & PROF & LIK & AGE \\
\hline Mean & 0.426392 & 2.333333 & 4.980858 & 0.846259 & 5.790011 & 8.595486 \\
Median & 0.434800 & 2.000000 & 4.592589 & 0.887403 & 5.348530 & 7.000000 \\
Maximum & 0.543500 & 3.000000 & 7.706460 & 1.472700 & 10.12466 & 25.00000 \\
Minimum & 0.326100 & 2.000000 & 3.654000 & -0.293600 & 2.955000 & 0.583333 \\
Std. Dev. & 0.074192 & 0.476393 & 1.066015 & 0.314942 & 1.568767 & 5.874550 \\
Skewness & -0.044420 & 0.707107 & 1.088801 & -2.283283 & 0.843098 & 1.426320 \\
Kurtosis & 1.803468 & 1.500000 & 3.292379 & 9.626122 & 3.294662 & 4.299278 \\
\hline
\end{tabular}

Uji mengenai determinan yang berpengaruh terhadap tingkat pengungkapan ISR mengunakan pendekatan Autoregresive Conditional Heteroskedasticity (ARCH). Model ARCH digunakan untuk mengestimasi koefisien variabel pada persamaan 2 karena data yang digunkan pada penelitian ini bersifat time series. Hasil regersi tampak pada tabel 4 . 
Tabel 4. Hasil Pengujian Hipotesa

\begin{tabular}{cccc}
\hline Variabel & Koefisien (Std. Error) & Ekspektasi koefisien & Kesimpulan \\
ICG & $-0,066382$ & Positif & ditolak \\
& $(0,023234) *$ & & ditolak \\
GCG & $-0,007385$ & Positif & ditolak \\
& $(0,007270)$ & & Positif \\
PROF & 0,006781 & & ditolak \\
& $(0,015215)$ & Positif & didukung \\
LIK & $-0,001917$ & & \\
& $(0,003660)$ & Positif & \\
AGE & 0,010666 & & \\
\end{tabular}

Tabel 4 menunjukkan determinan pertama yang mengharapkan ICG berpengaruh positif terhadap pengungkapan Islamic Social Reporting (ISR) ditolak. Dalam penelitian ini, Islamic Corporate Governance (ICG) menggunakan proksi ukuran atau jumlah dari Dewan Pengawas Syariah (DPS) yang terdapat di dalam perbankan syariah. Hasil penelitian ini mengindikasikan bahwa jumlah DPS yang lebih sedikit akan membuat pengawasan terhadap pemenuhan prinsip syariah dalam kegiatan usaha Bank Syariah lebih efektif. Tugas pokok DPS adalah dalam hal kepatuhan syariah, yaitu mengawasi apakah kegiatan perbankan syariah telah sesuai dengan prinsip syariah sehingga kurang memerlukan infomasi yang dimasukan dalam pengungkapan Islamic Social Reporting. Sesuai dengan Surat Edaran OJK No. 10/SEOJK.03/2014 bahwa jumlah anggota Dewan Pengawas Syariah paling kurang 2 (dua) orang atau paling banyak 50\% (lima puluh persen) dari jumlah anggota Direksi. Didalam penelitian ini rata-rata perbankan syariah memiliki 2 atau 3 Dewan Pengawas Syariah.

Hasil penelitian ini tidak sependapat dengan penelitian oleh Charles dan Chariri (2012) yang menyatakan bahwa Islamic Corporate Governance yang dihitung dari jumlah Dewan Pengawas Syariah dalam perbankan syariah memiliki pengaruh positif terhadap pengungkapan Islamic Social Reporting. Dewan Pengawas Syariah memiliki peranan penting bagi perkembangan perbankan syariah yang menunjukkan kredibilitas bank syariah. Penelitian Khoirudin (2013) menyatakan bahwa ukuran DPS tidak berpengaruh terhadap pengungkapan ISR. Menurut Rosiana (2015) Corporate Governance bagi bank syariah di Indonesia masih baru dan tergolong tahap pertumbuhan sehingga belum menjamin Islamic Corporate Governance suatu bank syariah yang baik akan lebih luas mengungkapkan Islamic Social Reporting.

Determinan ke dua juga tidak didukung data. Tabel 4 menunjukan bahwa kofisien Good Corporate Governance (GCG) yang diestimsi dengan menggunakan kepemilikan institusional, kepemilikan managerial, proporsi dewan komisaris independen dan komite audit mempunyai bernilai negatif dan tidak signifikan. Hasil ini sejalan dengan penelitian Charles dan Chariri (2012) bahwa GCG berpengaruh negatif terhadap pengungkapan ISR. penelitian Firdaus (2017) juga menunjukan bahwa kepemilikan institusional tidak berpengaruh terhadap pengungkapan ISR. Kepemilikan manajerial dari penelitian Assegaf, et al. (2012) juga berpengaruh negatif. Hasil ini juga mengimplikasikan bahwa semakin besar komposisi kepemilikan dalam manajemen tidak sejalan dengan pengungkapan ISR perusahaan yang juga semakin besar.

Di samping itu, aktivitas monitoring yang dilakukan investor institusi tidak mendorong manajemen untuk melakukan pengungkapan tanggung jawab sosial yang lebih luas. Menurut Ningrum, et al (2013), institusional shareholder dengan kepemilikan saham yang besar justru memiliki insentif untuk memantau pengambilan keputusan perusahaan. Apabila dikaitkan dengan pengungkapan tanggung jawab sosial, aktivitas monitoring yang dilakukan oleh investor institusi dapat memaksa manajemen untuk mengungkapkan informasi sosialnya. Akan tetapi, Elendri (2017) menunjukan bahwa jumlah komite audit berpengaruh positif terhadap pengungkapan ISR. Hal ini mengidentifikasi bahwa semakin besar ukuran komite audit, semakin efektif pelaksanaan pengawasan yang dilakukan sehingga pengungkapan dari ISR semakin tinggi.

Berdasarkan hasil pengujian yang disajikan pada tabel 4, diperoleh hasil bahwa profitabilitas (PROF) yang diestimasi dengan menggunakan indikator ROA, ROE, NPM, dan BOPO mempunyai nilai positif tetapi tidak signifikan. Hal tersebut menunjukkan bahwa determinan yang mengharapkan profitabilitas berpengaruh positif terhadap pengungkapan Islamic Social Reporting (ISR) ditolak. Menurut Haniffa (2002) menyatakan bahwa dalam pandangan Islam perusahaan yang memiliki niat untuk melakukan pengungkapan sosial penuh tidak akan mempertimbangkan apakah perusahaan tersebut untung atau rugi. Hal ini dikarenakan sebuah perusahaan tetap berusaha mengungkapkan informasi sosial dengan sebaik mungkin sebagai bentuk tanggungjawabnya meskipun dalam kondisi profitabilitas yang naik ataupun turun.

Hubungan profitabilitas dan tingkat pengungkapan ini sejalan dengan hasil penelitian Rosiana (2015) bahwa profitabilitas tidak berpengaruh untuk pengungkapan ISR. Karena perusahaan yang mempunyai profit tinggi cenderung belum tentu banyak melakukan aktivitas sosial karena perusahaan lebih berorientasi pada laba 
semata. Sedangkan pada saat perusahaan memperoleh laba yang rendah, maka terdapat persepsi bahwa pengguna laporan keuangan akan senang untuk membaca berita baik tentang kinerja perusahaan dalam bidang sosial. Walaupun dalam penelitian dari Ramadhani (2014); dan Widiyanti dan Hasanah (2015) mengungkapkan bahwa profitabilitas berpengaruh terhadap pengungkapan ISR. Profitabilitas yang tinggi menggambarkan bahwa perusahaan dapat menanggung biaya yang lebih tinggi untuk mengungkapkan informasi yang luas pada laporan pertanggungjawaban sosial.

Hasil determinan ke empat juga tidak didukung data. Tabel 4 menunjukan bahwa koefisien likuiditas (LIK) yang diestimasi dengan Quick Ratio, Current Ratio, Cash Ratio, dan Financing Deposits Ratio bernilai negatif dan tidak signifikan. Dengan demikian, harapan likuditas berpengaruh positif terhadap pengungkapan Islamic Social Reporting (ISR) ditolak. Hasil ini mengindikasikan bahwa pengungkapan ISR tetap dilakukan oleh perusahaan meskipun tingkat likuiditas perusahaan tinggi. sedang ataupun rendah. Karena dengan melakukan pengungkapan ISR, perusahaan tidak akan mengalami kerugian, dan juga tidak akan mempengaruhi dalam membayar hutang perusahaan dan tetap akan melaporkan tanggungjawab sosialnya.

Hasil ini juga sejalan dengan penelitian Lestari (2016) yang menyatakan bahwa likuiditas tidak berpengaruh terhadap pengungkapan ISR karena tingkat likuiditas tidak bisa dijadikan dalam evaluasi perusahaan yang dianggap akan berpengaruh pada pengungkapan tanggung jawab sosial. Hal ini menjadikan para kreditur tidak akan memandang dari adanya pengungkapan ISR dalam melihat keadaan atau situasi perusahaan, karena tinggi atau rendah tingkat likuiditas tidak tidak akan mengurangi pengungkapan ISR. Sebaliknya penelitian Widiyanti dan Hasanah (2015) berpendapat bahwa likuiditas berpengaruh untuk pengungkapan ISR. Menurut teori legitimasi, perusahaan berupaya meningkatkan kinerja keuangan demi mendapatkan sorotan publik. Kinerja keuangan yang ditunjukkan oleh kuatnya rasio likuiditas suatu perusahaan erat kaitannya dengan luasnya pengungkapan tanggung jawab sosial.

Determinan terakhir yang mengharapkan umur (AGE) perusahaan berpengaruh positif terhadap pengungkapan Islamic Social Reporting (ISR) didukung data. Tabel 4 menunjukan bahwa koefisien umur perusahaan bernilai positif dan signifikan. Hal ini mengimplikasikan bahwa perusahaan yang lebih lama berdiri cenderung akan mengungkapkan Islamic Social Reporting lebih banyak dari pada perusahaan yang baru berdiri. Dengan kata lain, pihak manajemen memberikan laporan pengungkapan ISR yang cakupannya luas untuk memberikan gambaran positif tentang perusahaan. Temuan penelitian ini sejalan dengan hasil penelitian Lestari (2016). Dia berpendapat bahwa perusahaan yang lebih lama berdiri mendapatkan kepercayaan yang lebih dari para investor dan stakeholder lainnya. Mereka menginginkan informasi dalam laporan tersebut lebih lebih banyak terutama yang berkaitan dengan pengembangan dan pertumbuhan perusahaan tersebut. Akan tetapi, penelitian dari Sunaryo dan Mahfud (2016) dan Fatoni (2016) menunjukan bahwa tidak terdapat pengaruh umur perusahaan terhadap pengungkapan social. Hal ini diartikan bahwa semakin lama perusahaan berdiri tidak berarti perusahaan tersebut semakin dapat menunjukkan eksistensi dalam lingkungannya. Umur perusahaan ternyata bukan merupakan faktor yang mempengaruhi kinerja perusahaan dalam mengungkapkan tanggungjawab sosialnya.

\section{Kesimpulan}

Penelitian ini dilakukan karena hasil penelitian-penelitian terdahulu yang tidak konsisten terhadap pengungkapan Islamic Social Reporting (ISR). Penggunaan indikator yang berbeda-beda pada penelitian terdahulu, menjadikan hasil yang tidak konsisten, sehingga penelitian ini menggunakan alat ukur tunggal untuk mengestimasi nilai determinan. Kesimpulan penting dan utama adalah bahwa semakin banyak jumlah DPS justru memungkinkan tidak efektifnya pengungkapan terhadap ISR, dan semakin lama perusahaan itu berdiri maka semakin tinggi tingkat pengungkapan ISR nya. Hasil penelitian ini juga menunjukan Good Corporate Governance, likuiditas, dan profitabilitas perusahan bukan merupakan determinan ISR.

Kedua, dengan menggunakan alat ukur tunggal berupa nilai efisiensi untuk determinan yang banyak memiliki proksi, penelitian mampu mengatasi kelemahan utama pada penelitian sebelumnya. Indikator-indikator yang berkaitan dengan variabel-variabel yang diteliti diikutkan seluruhnya, lalu dimasukkan ke dalam mekanisme matematis menggunakan analisis DEA. Dengan demikan, penelitian selanjutnya diharapkan dapat menggunakan pendekatan serupa untuk menghindari ketidakkonsistenan dan perbedaan dalam mengukur nilai suatu variabel.

Terakhir, hasil menunjukan tidak semua determinan secara signifikan mempengaruhi tingkat pengungkapan ISR bank umum syariah Indonesia. penelitian selanjutnya perlu menambahkan variabel lain seperti kepatuhan syariah. Peneltian selanjutnya juga bisa membandingkan tingkat pengungkapan Islamic Social Reporting dengan negara lainnya yang memiliki perbankan syariah.

\section{Referensi}

Anggraini, A., \& Mulyaning W. (2017). Faktor financial-non financial dan tingkat pengungkapan Islamic Social Reporting (ISR). Jurnal Akuntansi dan Keuangan Islam, 3 (2), 161-84. 
Arifah, A. (2018). Faktor-faktor yang mempengaruhi Islamic social reporting pada perusahaan yang listing di JII. Skripsi Program Studi Manajemen Keuangan Syariah, Universitas Islam Negeri Sunan Kalijaga, Yogyakarta.

Assegaf, Y. U., Falikhatun, \& Salamah W. (2012). Bank Syariah di Indonesia: corporate governance dan pengungkapan pertanggungjawaban sosial Islami (Islamic social responsibility disclosure), Conference In Business, Accounting and Management (CBAM), 1 (1), 255-67.

Astuti, T. (2013). Pengaruh profitabilitas, likuiditas dan leverage terhadap pengungkapan Islamic social reporting (studi empiris pada perusahaan yang terdaftar di JII tahun 2010-2012). https://www.iqtishadconsulting.com/assets/media/file/file-pengaruh-profitabilitas-likuiditas-danleverage-terhadap-pengungkapan-islamic-social-reporting-studi-empiris-pada-perusahaan-yangterdaftar-di-jii-tahun-2010-2012.pdf.

Charles \& Chariri. (2012). Analisis pengaruh Islamic corporate governance terhadap pengungkapan corporate social responsibility (studi kasus pada bank syariah di Asia), Diponegoro Journal of Management, 2(1), $1-15$.

Clarkson, M. (1995). A stakeholder framework and evaluating for analyzing and evaluating corporate social performnace. The Academy of Management Review, 20 (1), 92-117.

Dewi, S. S, \& Maswar, P. P. (2013). Pengaruh karakteristik perusahaan terhadap corporate social responsibility disclosure, Jurnal Ilmu \& Riset Akuntansi, 2(3), 326-44.

Eksandy, A, \& Zulman, M. H. (2015). Pengaruh ukuran perusahaan, profitabilitas, dan leverage terhadap pengungkapan Islamic social reporing (pada perbankan syariah di Indonesia tahun 2011-2015), Seminar Nasional dan the $4^{\text {th }}$ Call for Syariah Paper, Peran Profesi Akuntansi dalam Penanggulangan Korupsi. Universitas Muhammadiyah Surakarta, Surakarta. https://publikasiilmiah.ums.ac.id/bitstream/handle/11617/9214/4.\%20Arry\%20Eksandy.pdf?sequence= 1

Elendri, G. (2017). Pengaruh good corporate governance dan kinerja keuangan terhadap pengungkapan ISR (Islamic social reporting) pada bank umum syariah. Skripsi Fakultas Ekonomi, Universitas Islam Indonesia, Yogyakarta

Fatoni, Rita, A \& Kharis, R. (2016). Pengaruh kepemilikan publik, return on equity, current ratio, umur perusahaan dan company size terhadap pengungkapan corporate social responsibility pada perusahaan real estate dan property yang terdaftar di Bursa Efek Indonesia periode 2011-2014. Journal of Accounting, 2 (2), 1-15

Febrianty, F. (2017). Analisis rasio likuiditas dan profitabilitas pada Bank Rakyat Indonesia Syariah, Tugas Akhir Fakultas Ekonomi dan Bisnis Islam, Universitas Islam Negeri Raden Fatah, Palembang

Firdaus, I. (2017). Pengaruh kinerja keuangan, kepemilikan institusional, ukuran dewan pengawas syariah, leverage terhadap pengungkapan Islamic social reporting pada perbankan syariah di Indonesia (studi pada perbankan syariah tahun 2013-2015), JOM Fekon, 4 (1), 3095-3109.

Haniffa, R. (2002). Social reporting disclosure: An Islamic perspective, Indonesian Management \& Accounting Research, 1(2), 128-46.

Harahap, N., Hendra, H, Siregar, S, \& Nova, M. (2017). Pengaruh Islamic social reporting (Isr), umur perusahaan dan kepemilikan saham publik terhadap profitabilitas (ROA) pada perusahaan yang terdaftar di Jakarta Islamic Index (JII) Tahun 2010-2014, Kitabah, 1(1), 69-91.

Haribowo, I. (2015). Analisis Pengaruh Islamic corporate governance terhadap corporate social responsibility (studi kasus pada bank syariah di Indonesia), Jurnal Bisnis dan Manajemen, 5(1), 147-72.

Hartawati, E., Ni Luh, Gd. E. S., \& Putu, S. K. (2017). Kinerja sosial, kinerja lingkungan dan komite audit terhadap pengungkapan Islamic social reporting (ISR) pada perusahaan yang terdaftar di Jakarta Islamic Index ( JII ) periode tahun 2014-2016, E-Journal S1 Ak Universitas Pendidikan Ganesha, 8 (2). 1-12.

Jensen, M. C., \& William, H. M. (19760. Theory of the firm: managerial behavior, agency costs and ownership structure. Journal of Financial Economics, 3 (4), 305-60. doi:10.1016/0304-405X(76)90026-X.

Khoirudin, A. (2013). Corporate governance dan pengungkapan Islamic social pada perbankan syariah di Indonesia. Accounting Analysis Journal, 2(2), 227-32. 
Kusuma, H., \& Ariza, A. (2016). The corporate governance efficiency and Islamic bank performance: an Indonesian evidence, Polish Journal of Management Studies, 13 (1), 111-20. doi:10.17512/pjms.2016.13.1.11.

Lestari, S. (2016). Pengaruh tingkat profitabilitas, likuiditas, leverage, ukuran perusahaan dan umur perusahaan terhadap pengungkapan Islamic social reporting pada perbankan syariah Indonesia tahun 2010-2014, Jurnal Akuntansi Universitas Negeri Surabaya, 4(2), 1-24.

Lindawati, Ang, S. L., \& Marsella, E. P. (2015). Corporate social responsibility: implikasi stakeholder dan legitimacy gap dalam peningkatan kinerja perusahaan, Jurnal Akuntansi Multiparadigma, 6(1), 157-74. doi:10.18202/jamal.2015.04.6013.

Masyitah, E. (2016). Faktor-faktor yang mempengaruhi pengungkapan sosial (social disclosure) dalam laporan keuangan tahunan perusahaan manufaktur yang terdaftar di Bursa Efek Indonesia, Jurnal Al-Qasd, 1(1), $52-70$.

Nadlifiyah, N. F., \& Nisful, L. (2016). Analisis pengaruh kinerja perusahaan terhadap pengungkapan ISR bank umum syariah tahun 2010-2014, Jurnal Ekonomi Syariah Teori dan Terapan, 4(1), 44-61.

Nasir, A., Pipin, K., \& Teguh, D. H. (2013). Pengaruh kepemilikan manajerial, leverage, profitabilitas, ukuran, dan umur perusahaan terhadap pengungkapan informasi pertanggungjawaban sosial perusahaan pada perusahaan food and beverage yang terdaftar di BEI, Journal of Chemical Information and Modeling, 53(9), 1689-99. doi:10.1017/CBO9781107415324.004.

Ningrum, R. A., Fachrurrozie, \& Prabowo, Y. J. (2013). Pengaruh kinerja keuangan, kepemilikan institusional dan ukuran dewan pengawas syariah terhadap pengungkapan ISR, Accounting Analysis Journal, 2 (4), 43038.

Othman, R., Azlan Md. T., \& Erlane, K. G.. (2009). Determinants of Islamic social reporting among top shariah approved companies in bursa Malaysia.” Research Journal of International Studies, 12(12), 4-20.

Otoritas Jasa Keuangan. (2018). Statistik Perbankan Syariah - Desember 2018. https://www.ojk.go.id/id/kanal/syariah/data-dan-statistik/statistik-perbankan-syariah/Default.aspx.

Ramadhani, F. (2014). Pengaruh ukuran perusahaan, profitabilitas, leverage dan ukuran dewan pengawas syariah terhadap pengungkapan Islamic social reporting (studi empiris pada bank umum syariah di Indonesia tahun 2010-2014), JOM Fekon, 3(1), 2487-2500.

Ramdhaningsih, A., \& I Made, K. U. (2013). Pengaruh indikator good corporate governance dan profitabilitas pada pengungkapan corporate social responsibility, E-Jurnal Akuntansi Universitas Udayana, 3(3), 6582.

Rosiana, R., Bustanul, A., \& Muhamad, H.. (2015). Pengaruh ukuran perusahaan, profitabilitas, leverage, dan Islamic governance score terhadap pengungkapan Islamic social reporting (studi empiris pada bank umum syariah di Indonesia tahun 2010-2012), ESENSI, Jurnal Bisnis dan Manajemen, 5 (1), 87-104.

Santioso, L., \& Erline, C. (2012). Pengaruh profitabilitas, ukuran perusahaan, leverage, umur perusahaan dan dewan komisaris independen dalam pengungkapan corporate social responsibility, Jurnal Bisnis Dan Akuntansi, 14 (1), 17-30

Sunaryo, B. A., \& Mohammad, K. M.. (2016). Pengaruh size, profitabilitas, leverage dan umur terhadap pengungkapan tanggungjawab sosial perusahaan (studi empiris perusahaan manufaktur yang listing di BEI tahun 2010 - 2013), Diponegoro Journal of Management, 5 (1), 1-14.

Undang-Undang Republik Indonesia Nomor 21 Tahun 2008 Tentang Perbankan Syariah. 2008. Indonesia. https://www.ojk.go.id/id/kanal/syariah/data-dan-statistik/statistik-perbankan-syariah/Default.aspx.

Widiyanti, N. W., \& Nindya, T. H. (2015). Analisis determinan pengungkapan Islamic Social Reporting (ISR) (studi kasus pada perusahaan yang terdaftar di Jakarta Islamic Index (JII) tahun 2011-2015), Bisnis, 5 (2): $1-112$. 